\title{
GAMBARAN TINGKAT KECEMASAN PADA WANITA PEKERJA SEKSUAL USIA REMAJA DI KOTA MANADO (STUDI KUALITATIF TERHADAP 2 ORANG WANITA PEKERJA SEKSUAL USIA REMAJA)
}

\author{
${ }^{1}$ Audi Pirade \\ ${ }^{2}$ Theresia Kaunang \\ ${ }^{2}$ Anita Dundu
}

\author{
${ }^{1}$ Kandidat Skripsi Fakultas Kedokteran Universitas Sam Ratulangi Manado \\ ${ }^{2}$ Bagian Psikiatri Fakultas Kedokteran Universitas Sam Ratulangi Manado \\ E-mail: audi.batto@yahoo.com
}

\begin{abstract}
Female sexual worker is someone who sells herself to have sex rewarded in the form of money or something, they sell their bodies for getting some material. Prostitute has many risk factors that can lead to anxiety, both internal and external factors. The study aimed to find out about anxiety degree of adolescent female sexual workers in Manado city. This research is a quantitative study using cross-sectional method for 30 respondents about anxiety degree using Hamilton Anxiety Rating Scale, followed by qualitative study through in-depth interviews on 2 respondents. Respondents in both studies were selected by purposive sampling. From 30 respondents found 53,33\% experiencing severe anxiety, 30\% had moderate anxiety and 16,7\% respondents had mild anxiety. Conflicts that occur in female sexual worker can be caused by unpleasant experiences, job risk and self pressure because the profession are embarrassing and contradict to religious values, on the other hand they also need the job as a source of income. It becomes a dilemma and would cause anxiety. So, it can be concluded that majority of adolescent female sexual workers have severe anxiety degree, several factors that can induce anxiety are personal, family, job, environmental and religion factors.
\end{abstract}

Keyword: anxiety degree, adolescent female sexual workers, manado city.

\begin{abstract}
Abstrak: Wanita pekerja seksual adalah seseorang yang menjual diri dengan melakukan hubungan seks untuk memperoleh imbalan dalam bentuk uang maupun barang, mereka menjajakan tubuhnya demi mendapatkan sejumlah materi. WPS mempunyai banyak faktor resiko yang dapat menimbulkan kecemasan, baik faktor internal maupun eksternal. Tujuan penelitian ialah untuk mengetahui gambaran tingkat kecemasan WPS remaja di kota Manado. Penelitian ini merupakan penelitian kuantitatif dengan pengambilan data secara cross sectional terhadap 30 orang responden mengenai tingkat kecemasan menggunakan Hamilton Anxiety Rating Scale, dilanjutkan dengan penelitian kualitatif melalui wawancara mendalam terhadap 2 orang responden. Reponden dalam kedua penelitian dipilih dengan purposive sampling. Hasil uji HARS didapatkan 53,3\% responden mengalami kecemasan berat, 30\% responden mengalami kecemasan sedang, dan 16,7 \% responden mengalami kecemasan ringan. Konflik yang terjadi dalam diri WPS dapat disebabkan oleh pengalaman masa lalu, resiko pekerjaan serta tekanan dari dalam diri sendiri karena menganggap pekerjaan tersebut bertentangan dengan ajaran agama, disisi lain mereka juga membutuhkan pekerjaannya sebagai sumber penghasilan. Hal ini menjadi dilema dan menimbulkan kecemasan. Dari penelitian ini dapat disimpulkan bahwa sebagian besar WPS remaja di kota Manado memiliki tingkat kecemasan berat, beberapa faktor yang dapat menimbulkan kecemasan pada WPS remaja tersebut antara lain faktor pribadi, keluarga, pekerjaan, masyarakat dan agama.
\end{abstract}

Kata kunci: Tingkat kecemasan, WPS remaja, kota Manado 
Pekerja seksual adalah mereka yang menyediakan jasa seksual, dalam bentuk penyerahan tubuh kepada konsumen dengan imbalan berupa uang dan atau benda-benda berharga tertentu. Saat ini istilah pekerja seksual mengarah, baik kepada kaum wanita maupun pria, namun karena jumlah pekerja wanita lebih banyak sehingga lebih dikenal istilah wanita pekerja seksual (WPS). ${ }^{1}$

Kebanyakan orang menganggap WPS merupakan masalah dalam kehidupan bermasyarakat yang belum terselesaikan hingga sekarang dan berdampak buruk. Berprofesi sebagai WPS juga dianggap sebagai perbuatan yang tercela serta melanggar asusila sehingga keberadaannya dilarang dan pelakunya dapat dihukum. Akan tetapi pelacuran masih dapat dijumpai disetiap negara termasuk di Indonesia, baik dalam bentuk lokalisasi maupun yang dilakukan secara sembunyi-sembunyi. ${ }^{2}$

Di Indonesia sendiri pada tahun 2008 terdapat total 200.000-300.000 WPS yang menawarkan jasa seksual baik secara langsung maupun yang terselubung. ${ }^{1}$ Dalam survey terhadap 1.502 pekerja seksual di Jakarta, Surabaya, dan Manado, dari seluruh responden ditemukan 13,6\% sampel berusia 19 tahun kebawah. Survey ini juga memperlihatkan bahwa rata-rata umur WPS ketika pertama kali melakukan hubungan seks adalah kurang dari 17 tahun. $^{3}$

Remaja adalah masa transisi dari periode masa kanak-kanak menuju dewasa. Menurut Erikson masa remaja adalah masa terjadinya krisis identitas atau pencarian identitas diri. Remaja selalu berubah dan ingin selalu mencoba baik dalam peran sosial maupun dalam perbuatan, proses ini bertujuan untuk menemukan jati-diri atau identitasnya sendiri. ${ }^{4}$ Golongan remaja rentan terhadap kecemasan akibat berbagai pengaruh dari dalam maupun luar diri remaja sendiri. ${ }^{5}$

WPS merupakan pekerjaan yang erat hubungannya dengan kecemasan, banyak dari antara mereka memiliki tingkat kecemasan yang tinggi. Pada penelitian di kota Bandung tahun 2011 , dari 30 orang WPS yang diwawancarai 3.33\% dari mereka tidak mengalami kecemasan, $16.67 \%$ mengalami kecemasan ringan, 23.33\% dengan kecemasan sedang, 43.33\% dengan kecemasan berat, dan 13.33\% WPS mengalami kecemasan berat sekali. ${ }^{6}$

Sebagai ibu kota propinsi Sulawesi Utara, kota Manado mengalami proses modernisasi dalam berbagai aspek kehidupan. Modernisasi yang terjadi mempunyai pengaruh terhadap jumlah penduduk kota, keanekaragaman struktur sosial dan ekonomi, kebijaksanaan penggunaan sumber-sumber keuangan, kelembagaan kota dan sebagainya. Proses modernisasi yang terjadi tidak hanya memberikan dampak positif, ternyata banyak juga dampak negatif yang menimbulkan berbagai bentuk penyimpangan sosial, salah satunya ialah komersialisasi seks yang semakin meningkat. ${ }^{7}$ Menurut data KPA provinsi Sulawesi Utara, saat ini terdapat 498 WPS di kota Manado.

Saat ini penulis belum menemukan adanya penelitian tentang tingkat kecemasan pada WPS remaja di kota Manado padahal masa remaja merupakan masa pencarian identitas diri sehingga seseorang pada masa ini mudah labil dan rentan terhadap kecemasan, dan juga jumlah WPS remaja di kota Manado yang merupakan tujuan wisata seksual khususnya di daerah Indonesia bagian timur semakin meningkat dari tahun ke tahun. Berdasarkan uraian latar belakang diatas, penulis tertarik untuk meneliti tentang tingkat kecemasan WPS remaja di kota Manado.

\section{METODE PENELITIAN}

Penelitian ini merupakan penelitian kuantitatif dengan pengambilan data secara cross sectional terhadap 30 orang responden mengenai tingkat kecemasan menggunakan Hamilton Anxiety Rating Scale (HARS), dilanjutkan dengan penelitian kualitatif melalui wawancara mendalam terhadap 2 orang responden. Penelitian dilaksanakan di Corner café, Koulon café dan Hollywood café selama bulan November-Desember 
2013. Populasi penelitian adalah semua wanita pekerja seksual remaja di kota Manado. Sampel dalam kedua penelitian tersebut dipilih dengan purposive sampling yaitu peneliti memilih sampel berdasarkan pada pertimbangan bahwa responden tersebut dapat memberikan informasi yang memadai untuk menjawab pertanyaan penelitian. Kriteria eksklusi dalam penelitian ini ialah mereka yang mengalami penyakit tertentu dan atau keterbatasan fisik lainnya. Dalam penelitian kuantitatif variable yang digunakan ialah kecemasan dan karakteristik dari WPS remaja antara lain usia, tingkat pendidikan, suku, agama dan status ekonomi.

Definisi operasional kecemasan adalah suatu sinyal yang menyadarkan, memperingatkan adanya bahaya yang mengancam dan memungkinkan seseorang mengambil tindakan untuk mengatasi ancaman. Tingkat kecemasan terbagi atas kecemasan ringan, kecemasan sedang, kecemasan berat hingga panik, pada penelitian ini tingkat kecemasan diukur dengan menggunakan Hamilton Anxiety Rating Scale (HARS). HARS terdiri atas 14 item penilaian, masing-masing item terdiri atas rangkaian gejala serta dapat menilai kompenen psikis dan somatik kecemasan. Setiap item bernilai 0, 1, 2, 3 atau 4 dengan total skor antara 0-56. Istilah usia diartikan dengan lamanya keberadaan seseorang sejak dilahirkan yang dinyatakan dalam satuan waktu (tahun). Tingkat pendidikan mengacu pada jenjang pembelajaran yang sedang dijalani oleh responden yang diurutkan mulai dari tidak pernah sekolah, TK, SD, SMP, SMA/SMK hingga PT. Suku adalah nama daerah darimana responden berasal. Agama adalah keyakinan dan kepercayaan kepada Tuhan Yang Maha Esa yang dianut oleh setiap individu, saat ini pemerintah Indonesia mengakui 6 agama, yaitu Islam, Kristen Protestan, Kristen Katolik, Hindu, Buddha dan Kong Hucu. Sedangkan status ekonomi dilihat berdasarkan jumlah pendapatan yang diterima orang tua setiap bulan, dibagi menjadi kalangan ekonomi bawah, menengah dan atas.
Data yang diperoleh pada penilitian secara deskriptif dianalisis secara univariat untuk mengetahui frekuensi setiap variabel dan proporsinya terhadap tingkat kecemasan, adapun data yang diperoleh dari penelitian kualitatif akan dianalisa melalui tahapan proses reduksi/penyederhanaan data, penyajian data dan penarikan kesimpulan. Strategi untuk pengujian dan validasi data digunakan dengan metode triangulasi teknik pengumpulan data melalui observasi, kuesioner dan wawancara.

\section{HASIL}

\section{Karakteristik responden dan proposinya terhadap tingkat kecemasan}

\section{Proporsi tingkat kecemasan berdasarkan usia responden.}

Dari keseluruhan responden, 1 orang berusia 21 tahun, 14 orang berusia 20 tahun, 7 orang berusia 19 tahun, 5 orang berusia 18 tahun dan 3 orang berusia 17 tahun. Satunya-satunya responden (3,3\%) yang berumur 21 tahun mengalami kecemasan berat, pada responden yang berusia 20 tahun 7 orang (23,3\%) dengan kecemasan berat, kemudian kecemasan sedang 5 orang $(16,7 \%)$ dan kecemasan ringan 2 orang (6,7\%). Pada responden yang berusia 19 tahun terdapat 3 orang (10\%) yang mengalami kecemasan berat, 3 orang (10\%) mengalami kecemasan sedang dan 1 orang $(3,3 \%)$ mengalami kecemasan ringan. Responden yang berusia 18 tahun, sebanyak 4 orang $(13,3 \%)$ mengalami kecemasan berat dan 1 orang $(3,3 \%)$ mengalami kecemasan sedang. Sedang pada responden yang berusia 17 tahun, 1 orang (3,3\%) diantaranya mengalami kecemasan berat dan 2 orang $(6,7 \%)$ dengan kecemasan ringan.

\section{Proporsi tingkat kecemasan berdasarkan tingkat pendidikan responden}

Dari keseluruhan responden, 3 orang berpendidikan terakhir SMP, 25 orang SMA, dan 2 orang sementara mengikuti jenjang kuliah. Pada responden dengan tingkat pendidikan terakhir SMP 3 orang (10\%) mengalami kecemasan berat. Pada 
tingkat pendidikan terakhir SMA/SMK sebanyak 12 orang (40\%) mengalami kecemasan berat, 9 orang (30\%) mengalami kecemasan sedang 4 orang (13,3\%) dengan kecemasan ringan. pada responden yang sedang mengikuti jenjang kuliah 1 orang (3,3\%) mengalami kecemasan berat dan 1 orang $(3,3 \%)$ mengalami kecemasan ringan.

\section{Proporsi tingkat kecemasan berdasarkan suku responden}

Dari keseluruhan responden, 26 orang berasal dari suku Minahasa, 1 orang dari suku Bantik, 1 orang dari suku JawaMinahasa, 1 orang suku Sangihe dan 1 orang suku Munte. Responden dari suku Minahasa 13 orang (43,3\%) diantaranya mengalami kecemasan berat, 9 orang (30\%) mengalami kecemasan sedang, dan 4 orang (10\%) mengalami kecemasan ringan. Sementara itu, masing-masing responden yang berasal dari suku Bantik, JawaMinahasa dan Sangihe mengalami kecemasan berat, dan responden yang berasal dari suku mengalami kecemasan ringan.

\section{Proporsi tingkat kecemasan berdasarkan agama responden}

Dari keseluruhan responden, 2 orang beragama Islam, 1 orang beragama Kristen Katolik dan 27 orang beragama Kristen Protestan. Berdasarkan tingkat kecemasan

Tabel 1. Proporsi tingkat kecemasan berdasarkan usia

\begin{tabular}{cccccc}
\hline & \multicolumn{4}{c}{ Tingkat cemas } & Total \\
& & ringan & sedang & berat & \\
\hline \multirow{4}{*}{ usia } & 17 & 2 & 0 & 1 & 3 \\
& 18 & 0 & 1 & 4 & 5 \\
& 19 & 1 & 3 & 3 & 7 \\
& 20 & 2 & 5 & 7 & 14 \\
& 21 & 0 & 0 & 1 & 1 \\
\hline Total & & 5 & 9 & 16 & 30 \\
\hline
\end{tabular}

Tabel 2. Proporsi tingkat kecemasan berdasarkan tingkat pendidikan

Tingkat cemas Total menurut agama, responden yang beragama Islam 1 orang (3,3\%) mengalami kecemasan sedang, 1 orang lainnya (3,3\%) mengalami kecemasan ringan, sementara 1 orang (3,3\%) responden yang beragama Kristen Katolik mengalami kecemasan sedang, dan responden yang beragama Kristen Protestan yang mengalami kecemasan berat ada 16 orang (53,3\%), kecemasan sedang 7 orang $(23,3 \%)$, dan kecemasan ringan sebanyak 4 orang $(13,3 \%)$.

\section{Proporsi tingkat kecemasan berdasarkan status ekonomi keluarga responden}

Dari keseluruhan responden, 11 orang berasal dari kelas ekonomi bawah, 14 orang dari kelas menengah dan 5 orang orang dari kelas ekonomi atas. Responden yang berasal dari kelas ekonomi bawah 2 orang (6,7\%) mengalami kecemasan ringan, 4 orang $(13,3 \%)$ mengalami kecemasan sedang dan 5 orang (16,7\%) mengalami keceamasan berat. Responden yang berasal dari kelas ekonomi menengah 2 orang (6,7\%) mengalami kecemasan ringan, 3 orang (10\%) mengalami kecemasan sedang dan 9 orang (30\%) mengalami kecemasan berat. Responden dari ekonomi kelas atas, 1 orang (3,3\%) mengalami kecemasan ringan, 2 orang $(6,7 \%)$ mengalami kecemasan sedang dan 2 orang (6,7\%) dengan kecemasan berat.

\begin{tabular}{|c|c|c|c|c|}
\hline \multicolumn{5}{|c|}{ ringan sedang berat } \\
\hline SMP & 0 & 0 & 3 & \\
\hline PendidikanSMA/SMK & 4 & 9 & 12 & 25 \\
\hline $\mathrm{PT}$ & 1 & 0 & 1 & \\
\hline Total & 5 & 9 & 16 & \\
\hline
\end{tabular}


Tabel 3. Proporsi tingkat kecemasan

berdasarkan suku

\begin{tabular}{l|l|r|r|r|r}
\hline \multicolumn{2}{l|}{} & \multicolumn{3}{|c|}{ Tingkat cemas } & Total \\
ringan & sedang & berat & \\
\hline \multirow{5}{*}{ suku } & Bantik & 0 & 0 & 1 & 1 \\
& Jawa & 1 & 0 & 0 & 1 \\
Jawa- & & & & \\
\cline { 2 - 5 } & Minahasa & 0 & 0 & 1 & 1 \\
& Minahasa & 4 & 9 & 13 & 26 \\
& Sangihe & 0 & 0 & 1 & 1 \\
\hline Total & 5 & 9 & 16 & 30 \\
\hline
\end{tabular}

Tabel 4. Proporsi tingkat kecemasan berdasarkan agama

\begin{tabular}{l|l|r|r|r|r}
\hline \multicolumn{2}{l|}{} & \multicolumn{3}{|c|}{$\begin{array}{c}\text { Tingkat cemas } \\
\text { ringan }\end{array}$} & Total \\
\hline \multirow{4}{*}{ agama } & sedang & berat & \\
\hline & Islam & 1 & 1 & 0 & 2 \\
& Katolik & 0 & 1 & 0 & 1 \\
& Protestan & 4 & 7 & 16 & 27 \\
\hline Total & 5 & 9 & 16 & 30 \\
\hline
\end{tabular}
Tabel 5. Proporsi tingkat kecemasan berdasarkan sendiri. status ekonomi.

\begin{tabular}{llrrrr}
\hline & & \multicolumn{3}{c}{ Tingkat cemas } & \multicolumn{2}{c}{ Total } \\
& & ringan & sedang & berat & \\
\hline \multirow{2}{*}{ Status } & bawah & 2 & 4 & 5 & 11 \\
ekonomi & menengah & 2 & 3 & 9 & 14 \\
& atas & 1 & 2 & 2 & 5 \\
\hline \multirow{2}{*}{ Total } & 5 & 9 & 16 & 30 \\
\hline
\end{tabular}

\section{Hasil penelitian kualitatif}

Kegiatan penelitian kualitatif dilakukan di Corner café didaerah boulevard Manado, tanggal 16 November 2013, pukul 20:30 WITA terhadap 2 orang responden dengan tingkat kecemasan tinggi. Wawancara sendiri dilakukan dalam salah satu ruangan karaoke, situasi dalam ruangan cukup rapi, terdapat sofa sebagai tempat duduk, meja, satu set alat karaoke beserta layar monitor dengan ukuran besar namun pencahayaan didalamnya sangat redup.

\section{Kasus 1}

GA, 19 tahun, alamat Tikala (kost), agama Kristen Protestan, tamat sekolah menengah kejuruan (SMK), bungsu dari dua bersaudara. GA memilih tinggal sendiri di tempat kost karena kakaknya mengalami gangguan jiwa. Kakak GA pernah dirawat di Rumah Sakit Jiwa (RSJ) Ratumbuysang Manado selama 2 minggu karena gangguan jiwa tersebut. Sejak kecil GA rajin beribadah. Keadaan ekonomi keluarga GA termasuk kurang, ayahnya bekerja sebagai karyawan fotocopy dan ibunya sebagai ibu rumah tangga. GA sering merasa iri terhadap teman-temannya karena ia tidak bisa membeli barang-barang seperti temantemannya.

GA mulai berpacaran sejak kelas 1 SMK saat berusia 15 tahun dan pertama kali melakukan hubungan seksual saat berusia 16 tahun. Hubungan mereka telah berakhir karena komunikasi yang jarang setelah pacarnya kembali ke daerah asal di kota Palu, hal itu membuat ia sedih dan merasa

Ibu GA meninggal saat ia masih dibangku kelas 3 SMK akibat kecelakaan lalu lintas, saat itu ia merasa sangat sedih dan terpukul karena sejak kecil GA sangat 1 dekat dengan ibunya. Setelah ibunya 4 meninggal, ayah GA pindah ke Jakarta. 5 Awalnya ayah GA masih sering mengirimkan uang, tapi menurutnya jumlah uang tersebut tidak cukup. Saat ini GA kehilangan kontak dengan ayahnya. Oleh karena itu setelah lulus SMK ia mau mengikuti ajakan teman-temannya bekerja sebagai ladies di salah satu tempat karaoke hingga tengah malam untuk menemani pelanggan. Satu bulan bekerja sebagai ladies GA merasa penghasilannya hanya sedikit sehingga GA menerima ajakan dari temanteman lain menjadi ladies dan WPS secara "terselubung" di tempat tersebut. Dalam seminggu GA melayani 3-4 kali dengan total penghasilan perbulan sebesar Rp. 20.000.000. 
GA sering merasa cemas jika terinfeksi penyakit menular seksual (PMS) seperti gonorrhea, sifilis dan HIV-AIDS, sehingga ia meminta pelangganya menggunakan kondom. Jika pelanggan menolak GA merasa sangat khawatir tapi tidak menolak berhubungan. Ia juga takut jika hamil. Walaupun khawatir GA tidak pernah memeriksakan kesehatan ke dokter, hanya pernah 2 kali diskrening.

Uang yang diperolehnya digunakan untuk keperluan sehari-hari, ia juga berfoyafoya bersama teman-teman kost, tidak ada yang disisihkan untuk tabungan. Walaupun GA sudah mampu membeli segala keinginannya, GA merasa tindak berhasil. GA sering merasa bersalah dan berdosa terhadap Tuhan. GA merasa khawatir jika ayah dan teman-temannya tahu akan profesinya. Untuk menenangkan hati GA tetap rutin menjalankan ibadahnya. GA ingin berhenti tapi tidak tahu akan bekerja apalagi.

\section{Kasus 2}

LN, 20 tahun, sudah menikah dan mempunyai seorang anak berumur 10 bulan, agama kristen protestan, bersama suami tinggal dirumah kontrakan di daerah liwas. Sejak kecil LN jarang masuk ke gereja. Kedua orangtua LN bekerja sebagai pegawai negeri sipil di kota Manado, karena sangat sibuk dengan pekerjaan orangtua LN jarang mempunyai waktu luang bersama keluarga, namun kebutuhan LN dan adik-adiknya mampu dipenuhi mereka.

LN mulai berpacaran sejak kelas 1 SMA dan melakukan hubungan seksual pertama kali pada umur 16 tahun. Namun ia merasa dikhianati karena pacarnya itu ternyata sudah memiliki istri dan akhirnya ia memutuskan hubungan mereka berdua. LN kembali berpacaran saat kelas 3 SMA dengan seorang pria yang bekerja sebagai karyawan swasta dan sekarang telah menjadi suaminya. LN menikah setahun yang lalu, ia mengatakan dirinya sudah hamil sebelum menikah akibat seks bebas, hal itu membuat kedua orang tuanya sangat marah dan memintanya untuk keluar dari rumah.
Alasan LN masuk kedalam dunia prostitusi ialah karena faktor ekonomi, ia merasa kebutuhannya semakin bertambah sementara gaji suaminya tidak cukup. Setelah melahirkan, 3 bulan kemudian LN menerima ajakan dari teman-temannya bekerja sebagai ladies dan WPS "terselubung" di salah satu tempat karaoke. Suami LN telah mengetahui profesinya ini. Ketika bekerja sang suamilah yang merawat anak mereka, namun saat ini mereka telah memperkerjakan seorang babysitter. Saat ini kualitas hubungan seksual dengan suaminya menjadi berkurang, terkadang suaminya malas bahkan menolak untuk berhubungan. LN merasa khawatir apabila suami mempunyai wanita idaman lain.

LN bekerja tiap hari dan diantarjemput oleh suami ketempat karaoke, penghasilannya rata-rata Rp.15.000.000 perbulan. Ia menganjurkan pelanggannya menggunakan kondom karena takut terinfeksi PMS seperti hiv-aids, gonorea, dan lain-lain. LN sangat jarang memeriksakan kesehatan reproduksinya, dia hanya pernah 2 kali discreening, ia juga takut mengalami kekerasan fisik oleh pelanggan.

LN merasa bersalah dan malu terhadap Tuhan dan orangtuanya. LN takut pandangan masyarakat yang negatif tentang dirinya dapat berimbas pada anaknya. Ia ingin berhenti dari pekerjaan ini. Untuk menenangkan perasaan LN sering menceritakan isi hatinya kepada sang suami.

\section{BAHASAN}

Jumlah sampel yang berpartisipasi dalam penelitian mengenai tingkat kecemasan pada WPS di kota Manado ialah sebanyak 30 orang, berbeda dengan penelitian yang dilakukan oleh Cwikel, $\mathrm{dkk}^{8}$ dimana mereka menggunakan 55 WPS pada kompleks lokalisasi sebagai sampel dalam penelitian yang dilakukan di 3 kota berbeda namun teknik pengambilan sampel yang sama yaitu purposive sampling.

Penelitian ini menunjukkan bahwa WPS remaja berada periode late 
adolescence, akan terjadi perubahan fisik yang sangat mencolok pada periode ini, selain itu seorang individu akan berusaha menenemukan identitas diri yang sesungguhnya, cenderung akan berpikir abstrak dan kompleks serta mulai melakukan suatu hubungan khusus dengan lawan jenis. ${ }^{9}$ Hal ini sesuai dengan penelitian yang dilakukan oleh Wittchen, $\mathrm{dkk}^{10}$ yang menyimpulkan bahwa gangguan kecemasan dapat terjadi pada semua usia dan lebih banyak pada wanita.

$$
\text { Sebagian besar responden }
$$

mempunyai pendidikan terakhir ditingkat SMA/SMK, artinya sudah melalui program wajib belajar sehingga tingkat pendidikan pada WPS dapat dikatakan cukup memadai. Sementara itu dari hasil penelitian Rossler $\mathrm{dkk},{ }^{11}$ lebih dari setengah total responden telah mengikuti pendidikan khusus. Pendidikan seseorang akan berpengaruh terhadap kemampuan berfikir, semakin tinggi tingkat pendidikan akan semakin mudah berfikir rasional dan semakin mudah menangkap informasi baru termasuk dalam menguraikan permasalahan baru, namun dalam penelitian ini tidak terdapat kecenderungan hubungan antara tingkat pendidikan dengan tingkat kecemasan, hal ini didukung oleh hasil peneletian yang dilakukan oleh Byrne,dkk ${ }^{12}$

Responden yang berpartisipasi kebanyakan berasal dari suku Minahasa, hanya sebagian kecil responden yang berasal dari suku non-minahasa karena kota manado juga didiami pula oleh orang-orang yang berasal dari Sangihe, Talaud, Bolaang Mongondow, Gorontalo, serta ada pula pendatang yang berasal dari Jawa, Bugis, Makasar, Toraja, Ternate, dan daerah lain. ${ }^{13}$ Walaupun mayoritas WPS remaja dari suku Minahasa mengalami kecemasan berat, secara keseluruhan kecenderungan ini belum bisa menjadi bukti yang kuat dikarenakan tidak seimbangnya jumlah sampel berdasarkan asal suku.

Sebagian besar responden bergama kristen protestan karena mayoritas suku Minahasa beragama kristen protestan, hal ini sesuai dengan sensus penduduk kota manado tahun 2010 dimana penduduk yang beragama kristen protestan berjumlah $62 \%$ dari total penduduk, sementara penduduk yang beragam muslim 31\%, katolik 5\%, budha $1 \%$, hindu $0,5 \%$, kong hu-chu $0,5 \% .{ }^{14}$ Berdasarkan pada agama, mayoritas semuanya mengalami kecemasan dengan derajat yang berbeda-beda.

Menurut status ekonominya hampir setengah responden berasal dari kalangan ekonomi kelas menengah, berbeda dengan penelitian Purnama,dkk dimana dari 55 orang WPS sebagian besar responden berasal dari kalangan ekonomi kelas bawah, dan kebanyakan orang tua mereka bekerja sebagai buruh tani. ${ }^{15}$ Dalam penelitian ini semua tingkatan ekonomi mayoritas respondennya memiliki kecemasan berat. Sementarara itu Murphy,dkk ${ }^{16}$ dalam penelitiannya mengemukakan terdapat prevalensi yang signifikan antara depresi dan status sosioekonomi, dimana kecenderungannya terjadi pada populasi yang berada pada kelas bawah.

\section{Penelitian kualitatif}

\section{Dinamika kasus 1 dan pembahasan}

Keluarga GA termasuk keluarga yang kurang mampu. Penghasilan ayahnya yang pas-pasan hanya cukup untuk memenuhi kebutuhan keluarga sehari-hari, sehingga keinginannya untuk mempunyai mainan dan pakaian seperti teman-temannya tidak terpenuhi. Apabila keinginannya tidak terpenuhi GA hanya memendam rasa sedihnya. Ia tidak menunjukkan sikap bermusuhan dengan teman-temanya karena orang tuanya mengajarkan kepada GA untuk berprilaku baik kepada semua orang dan menunjukkan sikap sopan santun dalam pergaulan. Saat kecil GA mengalami konflik yang nyata antara id dan ego, id yang menuntut pemuasan segera dalam bentuk keinginan untuk memiliki pakaian dan permainan yang sama seperti milik temantemannya, mendapat tantangan dari realitas yang ada untuk tidak memaksakan kehendak, karena ekonomi keluarga yang kurang. Keinginan yang tidak terpenuhi ini 
pada akhirnya membawa GA dalam keadaan cemas.

Menurut teori psikoanalitik Sigmund Freud, kepribadian terdiri dari tiga unsur yaitu id, ego dan superego yang bekerja sama untuk menciptakan perilaku manusia yang kompleks. Id merupakan komponen kepribadian yang hadir sejak lahir, id didorong oleh pleasure principle, yang berusaha untuk memperoleh kepuasan segera dari keinginan dan kebutuhan. Ego adalah komponen keperibadian yang bertanggung jawab terhadap realitas, ego bekerja berdasarkan reality principle, yang berusaha untuk memuaskan keinginan id dengan cara-cara realistis yang sesuai dengan keadaan sosial. Super ego merupakan unsur kepribadian yang terbentuk melalui proses internalisasi nilai dan moral yang diperoleh dari orang tua dan masyarakat. $^{17}$

Kematian ibunya dan kepergian ayahnya ke Jakarta semakin membuat ia merasa kesepian apalagi takut tinggal bersama kakaknya. Delisle ${ }^{18}$ mendefinisikan kesepian sebagai keterasingan individu dari dirinya dan dunia luar yang merupakan keadaan emosional sebagai bentuk perilaku atau persepsi pada setiap periode kehidupan. Kesepian merupakan salah satu penyebab kecemasan, beberapa orang menjadi cemas karena mereka hidup terpisah dengan orangorang terdekat.

Bekerja sebagai WPS membuat GA harus berhadapan dengan banyak pria dengan berbagai latar belakang, ia takut mendapat perlakuan kasar hingga tindak kekerasan dari pelanggannya. Ia selalu meminta pelangganya untuk menggunakan kondom takut terinfeksi PMS dan hamil, namun ada saja pelanggan yang menolak dan langsung berhubungan seksual, hal itu sering membuat ia merasa cemas.

GA takut jika ayahnya dan saudarasaudaranya yang lain mengetahui profesinya ini. GA juga khawatir akan adanya razia yang dilakukan oleh pihak keamanan, ia merasa bersalah dan berdosa di hadapan Tuhan karena profesinya ini bertentangan dengan ajaran dan nilai-nilai agama yang ia sudah dapatkan sejak kecil.

Freud membagi kecemasan menjadi tiga jenis yaitu kecemasan realitas, kecemasan neurosis dan kecemasan moral. ${ }^{17}$ Pada kasus ini kecemasan yang terjadi termasuk jenis kecemasan moral, Ketika individu termotivasi untuk mengekspresikan impuls instingual yang berlawanan dengan nilai moral yang termaksud dalam superego individu itu maka ia akan merasa malu atau bersalah. Kecemasan moral menjelaskan bagaimana berkembangnya superego. Biasanya individu dengan kata hati yang kuat akan mengalami konflik yang lebih hebat daripada individu yang mempunyai kondisi toleransi moral yang lebih longgar. Rasa malu dan perasaan bersalah menyertai kecemasan moral. Dapat dikatakan bahwa yang menyebabkan kecemasan adalah kata hati individu itu sendiri.

\section{Dinamika kasus 2 dan pembahasan}

LN berasal dari keluarga yang berkecukupan, sejak kecil kebutuhannnya selalu dipenuhi, hal ini membuat LN tumbuh menjadi anak yang malas dan manja. Dia berprilaku semaunya karena perhatian dan kontrol dari orang tua yang sangat kurang dan cenderung memberi kebebasan. Menurut Wenar, ketiadaan kontrol dari orang tua akan menyebabkan perilaku yang menyimpang, karena dampak dari kehilangan tersebut sangatlah dirasakan sebagai suatu penolakan atau pun pengabaian. ${ }^{19}$

Erikson menyatakan ada dua aspek yang berpengaruh pada efektivitas proses sosialisasi orang tua terhadap anak, pertama yaitu parenteral control yang menunjukan sejauh mana orangtua mengharapkan kematangan dan tanggung jawab dari anak, kedua yaitu parenteral responsiveness yang menunjukkan sejauh mana orang tua member tanggapan terhadap kebutuhan anak-anak. Bertitik tolak dari dua aspek ini Baumrind menggolongkan gaya asuh orang tua menjadi empat sifat dengan dimensi control dan respon yang berbeda-beda, ada pola asuh yang bersifat authoritarian 
parenting (kontrol tinggi-respon rendah), authoritative parenting (kontrol tinggirespon tinggi), indulgent (control rendahrespon tinggi), dan indifferent parenting (control rendah-respon rendah). ${ }^{20}$

Dalam kasus ini, pola asuh orang tua LN mengarah kebentuk yang ketiga yaitu indulgent. Anak yang dimanja sejak kecil dapat menjadi terlalu bergantung terhadap orang tua sehingga saat dewasa akan mengalami kesulitan dan tidak bahagia apabila jauh dengan orang tua. Menurut Freud kecemasan juga dapat terjadi apabila seorang individu tidak pernah mengalami konflik sama sekali antara ketiga unsur kepribadian. $^{17}$

Pada kasus ini, LN yang dulunya sangat bergantung terhadap orang tua kini harus hidup mandiri dengan suaminya, tidak ada bantuan dari siapapun sehingga ia harus membantu suami dalam memenuhi kebutuhan keluarga serta keperluan sang anak.

Berprofesi sebagai WPS membuat dirinya takut apabila nanti terinfeksi PMS sehingga selalu meminta pelanggannya menggunakan kondom. Seringkali suami LN menolak untuk berhubungan seksual merasa cemas apabila suami mempunyai wanita idaman lain, hal ini menjadi konflik internal dalam keluarga. Terdapat tiga tingkatan mengenai konflik yang terjadi antara suami istri. Tingkatan pertama adalah the unvisible conflict. Konflik yang terjadi pada tingkatan ini masih ada di batin atau perasaan. Tingkatan kedua adalah the perceived / experienced conflict. Konflik yang terjadi pada tingkatan ini sudah sama-sama diketahui, dialami atau sudah tampak di permukaan. Tingkatan ketiga adalah the fighting. Pada tingkatan ini, konflik sudah berubah menjadi tindakan fisik. ${ }^{21}$

LN merasa malu dan bersalah apalagi kalau kelak anaknya besar dan mengetahui ia merupakan seorang WPS. Kecemasan yang terjadi pada LN juga diakibatkan karena perasaan takut mendapat stigma negatif yang dapat berimbas kepada anaknya dan dikucilkan dari masyarakat sekitar, serta perasaan berdosa kepada Tuhan akibat pekerjaan yang ia jalani ini.

\section{SIMPULAN}

Seluruh WPS usia remaja di kota Manado mengalami kecemasan, dengan tingkat kecemasan berat yaitu 53,3\%, tingkat kecemasan sedang sejumlah $30 \%$ dan tingkat kecemasan ringan sejumlah 16,67\% yang diukur dengan HARS. Faktor-faktor yang dapat menimbulkan kecemasan pada WPS usia remaja antara lain faktor pribadi, keluarga, pekerjaan, masyarakat dan agama.

\section{DAFTAR PUSTAKA}

1. Kendall M, Karina R. Sex work and HIV Indonesia. HIV and AIDS Data Hub for Asia-Pacific. 2010:1.

2. Erianjoni, Ikhwan. Pola dan jaringan prostitusi terselubung di kota Padang. Humanus. 2012; 11:112.

3. Irianto S. Perempuan dan hukum : menuju hukum yang berperspektif kesetaraan dan keadilan, edisi 1. Jakarta: Yayasan obor Indonesia. 2006:284.

4. Papalia DE, Old SW, Feldman RD. Human development. edisi 9 .Jakarta: Kencana; 2008. h. 534-8.

5. Surtress R. Pekerja seks komersial. In: Rosenberg R, editors. Perdagangan perempuan dan anak di Indonesia. Jakarta: United States Agency for International Development; 2003. h. 71-117.

6. Sihombing JPT, Hutagalung KR. Gambaran Kecemasan pada Pekerja Seks Komersial (PSK) di Bandung. Jurnal Kedokteran Maranatha. 2011; 11:56-62.

7. Pramono SA. Dampak perkembangan kota terhadap lingkungan sosial masyarakat. Teodolita. 2006; 7:47.

8. Cwikel J, Ilan K, Chudakov B. Women brothel workers and occupational health risks. J Epidemiol Community Health. 2003; 57(10):809.

9. Soetjiningsih. Pertumbuhan somatik pada remaja. In: Soetjiningsih, editor. Tumbuh kembang remaja dan permasalahannya. Jakarta: Sagung seto; 2007. h. 2-12.

10. HU Wittchen, J Hoyer. Generalized anxiety disorder: nature and course. J Clin Psychiatry. 2001; 62 (11):15-9. 
11. W. Rossler, U. Koch, C. Lauber2, A.-K. Hass, M. Altwegg,V. Ajdacic-Gross, K. Landolt. The mental health of female sex workers. Acta Psychiatr Scand. 2010: 3.

12. Byrne R, JM Joesch, PS Wang, RC Kessler. Low socioeconomic status and mental health care use among respondents with anxiety and depression in the NCS-R. Psychiatr Serv. 2009 Sep; 60(9):1190-7.

13. Berdame DY. Migrasi dan kepadatan penduduk di kota Manado. 2013 [cited 2014 Jan 21]; 8. Available from: http://sulut.bkkbn.go.id/AnalyticsReports.

14. Sensus penduduk 2010 - Penduduk menurut wilayah dan agama yang dianut provinsi Sulawesi utara. Badan Pusat Statistik. [cited 2014 Jan 21]. Available from: http://www.bps.go.id.

15. Purnama HC. Karakteristik sosiodemografi dan ekonomi pekerja seks komersial (PSK) di Kabupaten Situbondo. 2013:1. (Inpress).

16. JM Murphy, DC Oliver, RR Monson, AM Sobol, EB Federman, AH Leighton. Depression and anxiety in relation to social status. A prospective epidemiologic study. Arch Gen Psychiatry. 1991 Mar; 48(3):2239.

17. Andri, P Yenny Dewi. Teori Kecemasan Berdasarkan Psikoanalisis Klasik dan Berbagai Mekanisme Pertahanan terhadap Kecemasan. Maj Kedokt Indon. 2007; 57(7):235-8.

18. Hossen Abul. Social Isolation and Loneliness among Elderly Immigrants: The Case of South Asian Elderly Living in Canada. Journal of International Social Issues. 2012; 1(1):3.

19. Rini JF. Penyiksaan dan pengabaian terhadap anak [serial online]. 2008 [ cited 2014 Jan 15]. Available from: http://www.epsikologi.com/artikel/anak.

20. Alizadeh S, Talib $\mathbf{M}$, Abdullah $\mathbf{R}$. Relationship between Parenting style and Children's behavior problems. Asian Social Science. 2011 Dec; 7(12):196-8.

21. Opotow S. Denial and the process of moral exclusion in environmental conflict. Journal of Social Issue. 2000;56(3):475-8. 